\title{
Paraneoplastic Antibody
}

National Cancer Institute

\section{Source}

National Cancer Institute. Paraneoplastic Antibody. NCI Thesaurus. Code C162640.

Any autoantibody produced by an individual org anism in response to antigens expressed

by a neoplasm present in that individual. These antibodies can cause harmful

autoimmune responses in tissues or organs that are distant from the site of the neoplasm. 